\title{
METODE VACUUM CONSOLIDATION DENGAN PRELOADING UNTUK MEMPERCEPAT KONSOLIDASI TANAH PADA PERUMAHAN DI TANGERANG
}

\author{
Jason Sastilaya ${ }^{1}$ dan Gregorius Sandjaja ${ }^{2}$ \\ ${ }^{1}$ Program Studi Sarjana Teknik Sipil, Universitas Tarumanagara, Jl. Letjen S. Parman No.1 Jakarta \\ jason.325160170@stu.untar.ac.id \\ ${ }^{2}$ Program Studi Sarjana Teknik Sipil, Universitas Tarumanagara, Jl. Letjen S. Parman No.1 Jakarta \\ gregoriuss@ft.untar.ac.id
}

Masuk: 06-01-2021, revisi: 13-01-2021, diterima untuk diterbitkan: 11-02-2021

\begin{abstract}
Soil conditions in Kosambi City are soft soil with high moisture content and soil plasticity, low permeability and soil bearing capacity, and high pore water pressure. This soft soil condition makes the consolidation decline take a very long time. To solve the problem of the consolidation settlement duration, it is necessary to improve the land. The soil improvement is being carried out, namely the method of vaccum consolidation with preloading. The combination of these methods is carried out by installing a vertical drainage system in the form of prefabricated fabricated drain in soft soil, then the initial load is given in the form of preloading on the soil. The calculation results show that the amount of consolidation reduction that occurs when clay soil is loaded with a stockpile of 1,2 $m$ high, a water surcharge of $1.3 \mathrm{~m}$ and a vaccum load is 1,0048 $\mathrm{m}$ and 1,7427 $\mathrm{m}$. The combined method of preloading and PVD is proven to be able to accelerate the time of consolidation, where preloading and PVD are installed in a triangle pattern between $0,80 \mathrm{~m}$ to a depth of $12 \mathrm{~m}$, capable of achieving a consolidation degree of $90 \%$ within 8 weeks.
\end{abstract}

Keywords: Vacuum consolidation, prefabricated vertical drain, preloading, consolidation time.

\begin{abstract}
ABSTRAK
Kondisi tanah di Kosambi City merupakan tanah lunak dengan kadar air dan plastisitas tanah yang tinggi, permeabilitas dan daya dukung tanah yang rendah, serta tingginya tekanan air pori. Kondisi tanah lunak ini membuat penurunan konsolidasi membutuhkan waktu yang sangat lama. Untuk mengatasi masalah lamanya waktu penurunan konsolidasi ini, perlu dilakukan perbaikan tanah. Perbaikan tanah yang dilakukan yaitu metode vaccum consolidation dengan preloading. Kombinasi pada metode ini dilakukan dengan cara memasang sistem drainase vertikal berupa prefabricated fabricated drain di dalam tanah lunak, kemudian diberikan beban awal yaitu berupa timbunan (preloading) pada tanah tersebut. Hasil perhitungan menunjukkan besar penurunan konsolidasi yang terjadi jika tanah lempung dibebani dengan timbunan setinggi 1,2 m, water surcharge setinggi 1,3 m dan beban vaccum adalah 1,0048 m dan 1,7427 m. Metode kombinasi preloading dan PVD terbukti mampu mempercepat waktu konsolidasi, dimana preloading dan PVD dipasang dengan pola segitiga berjarak 0,80 m hingga kedalaman $12 \mathrm{~m}$, mampu mencapai derajat konsolidasi $90 \%$ dalam waktu 8 minggu.

Kata kunci: Vacuum consolidation, prefabricated vertical drain, preloading, waktu konsolidasi.
\end{abstract}

\section{PENDAHULUAN}

Indonesia merupakan negara yang memiliki banyak daerah pesisir. Tanah yang berada di pesisir cenderung merupakan jenis tanah lunak. Tanah lunak merupakan jenis tanah yang memiliki kuat geser yang rendah, koefisien permeabilitas yang kecil, kompresibilitas yang rendah, dan daya dukung tanah yang rendah. Kondisi tanah lunak ini membuat penurunan konsolidasi membutuhkan waktu yang sangat lama. Metode perbaikan tanah yang digunakan pada permasalahan waktu konsolidasi yang sangat lama ini yaitu metode vacuum consolidation dengan preloading.

Salah satu kawasan yang memakai vacuum consolidation method dengan preloading berada di proyek perumahan di Kosambi City, Tangerang (Sumber: Junaidy, 2020). Jenis tanah di Kosambi City, Tangerang adalah tanah lempung. Untuk mengatasi waktu penurunan konsolidasi yang sangat lama, digunakan metode vacuum consolidation dengan preloading. Komponen utama pada metode vacuum consolidation dengan preloading adalah adanya pemasangan prefabricated vertical drain (PVD). Pemberian beban awal (preloading) untuk meningkatkan tegangan air pori tanah sehingga proses konsolidasi dapat berjalan. Tujuan pemasangan prefabricated vertical 
Metode Vacuum Consolidation dengan Preloading untuk Mempercepat Konsolidasi Tanah pada Perumahan di Jason Sastilaya, et al. Tangerang.

drain (PVD) yaitu memperpendek jarak aliran air drainase tanah sedangkan vacuum akan mempercepat kecepatan aliran ke arah radial.

Perhitungan analisis peningkatan parameter tanah dan konsolidasi dapat dilakukan secara perhitungan pendekatan manual berdasarkan acuan geoteknik Indonesia.

\section{Identifikasi Tanah}

Saat melakukan perencanaan fondasi, identifikasi tanah berfungsi sebagai acuan awal dalam memprediksi sifat tanah. Metode klasifikasi tanah yang dipakai menggunakan the Dutch mechanical friction sleeve penetromoter (Searle, 1979) (Gambar 1). Indeks pemampatan (Cc) didapat melalui grafik korelasi qc dan Cc (Sanglerat, 1972) (Gambar 2).

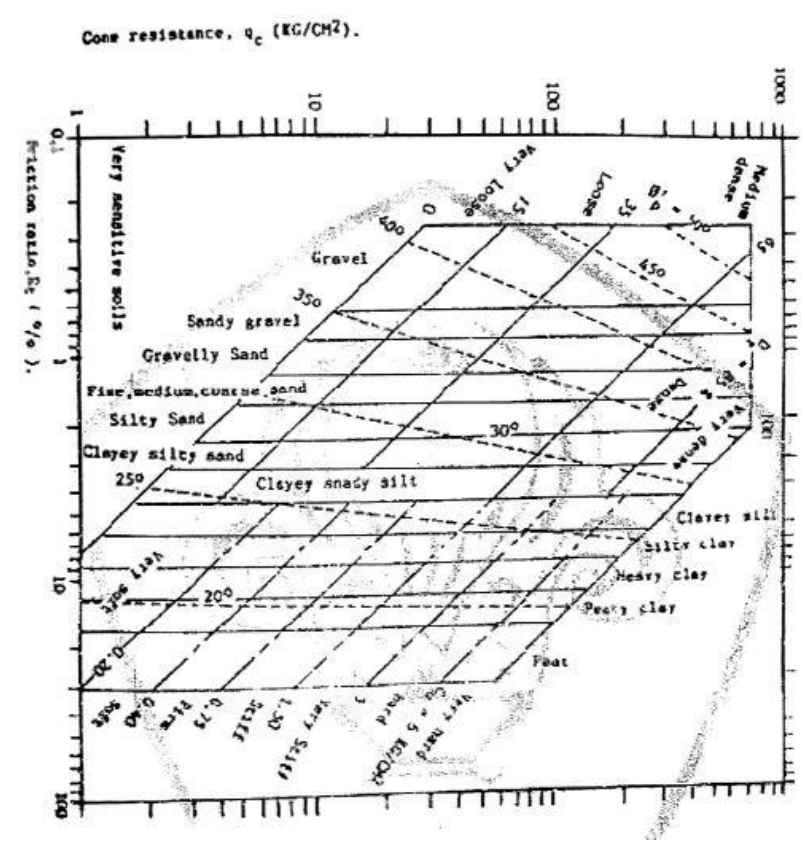

Gambar 1. Identifikasi tanah menggunakan the Dutch mechanical friction sleeve penetrometer.

(Searle, 1979)

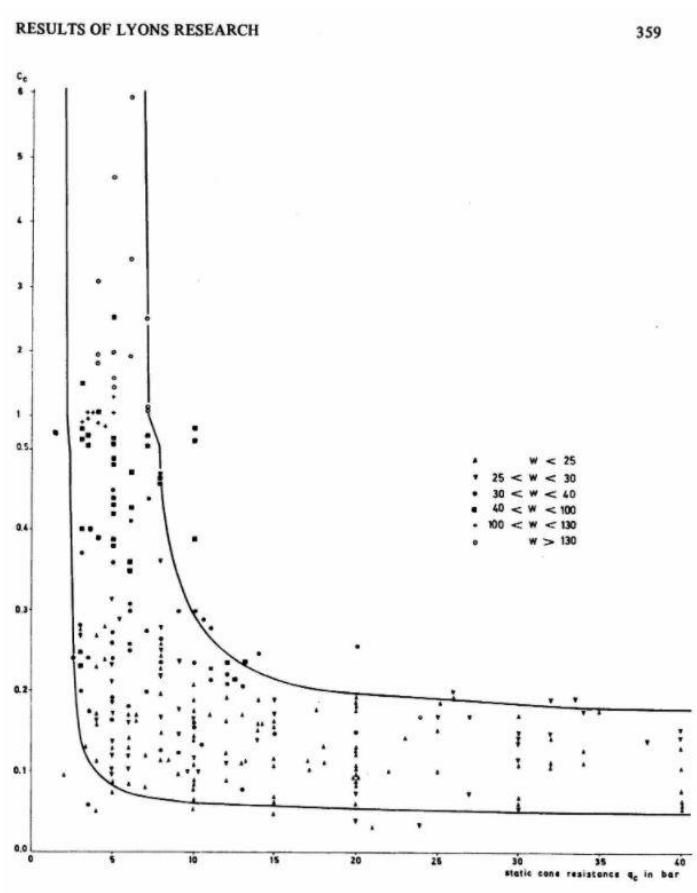

Fig. 188. $C_{\mathrm{c}}$ versus $q_{\mathrm{c}}$. (Note change of vertical scale between 1-0.5.)

Gambar 2. Grafik korelasi qc dengan Cc.

(Sanglerat, 1972)

\section{Penurunan Konsolidasi}

Penurunan konsolidasi primer dapat dihitung dengan persamaan berikut (Das, 2011):

Untuk normally consolidated soil $(\mathrm{OCR}=1) ; \mathrm{Pc}^{\prime}=\mathrm{P}_{0}$, dengan persamaan sebagai berikut:

$$
\mathrm{Sc}=\frac{\mathrm{CcH}}{1+e 0} \log \left(\frac{P 0+\Delta \mathrm{P}}{P 0}\right)
$$

Bila didefinisikan bahwa $\mathrm{P}_{1}=\mathrm{P}_{0}+\Delta \mathrm{P}$

$$
\mathrm{S} \quad=\mathrm{Cc} \frac{H}{1+e 0} \log \frac{P 1}{P 0}
$$

dengan $\mathrm{Cc}=$ indeks pemampatan, $\mathrm{H}=$ tebal lapisan tanah $(\mathrm{m})$, eo = angka pori awal, $\Delta \mathrm{P}=$ tambahan tegangan efektif $\left(\mathrm{KN} / \mathrm{m}^{2}\right)$, Po = tekanan overburden efektif awal sebelum dibebani $\left(\mathrm{KN} / \mathrm{m}^{2}\right)$.

\section{Kecepatan Penurunan Konsolidasi}

Kecepatan penurunan konsolidasi dihitung dengan persamaan (Terzaghi, 1943): 


$$
\mathrm{Tv}=\frac{\mathrm{Cv} \cdot \mathrm{t}}{H d r^{2}}
$$

dengan $\mathrm{Tv}=$ time factor (tanpa satuan), $\mathrm{Cv}=$ koefisien konsolidasi $\left(\mathrm{m}^{2} / \mathrm{dtk}\right), \mathrm{T}=$ waktu (detik), Hdr $=$ jarak lintas drainase terpanjang (meter).

Berdasarkan derajat konsolidasi (U\%) yang didapat atau diinginkan, Tv diketahui melalui persamaan (Das, 2011):

$$
\begin{aligned}
& \text { Untuk } \mathrm{U}=0-60 \%, \mathrm{Tv}=\frac{\pi}{4} \cdot\left(\frac{U \%}{100}\right)^{2} \\
& \text { Untuk } \mathrm{U}>60 \%, \mathrm{Tv}=1,781-0,933 \log (100-\mathrm{U} \%)
\end{aligned}
$$

dengan $\mathrm{U}=$ derajat konsolidasi $(\%)$

\section{Prefabricated Vertical Drain (PVD)}

Penentuan waktu konsolidasi oleh Hansbo (1979) dalam Mochtar (2012) dapat dibuat dengan persamaan:

$$
t=\left(\frac{D^{2}}{8 \cdot C h}\right) \cdot 2 \cdot F(n) \cdot \ln \left(\frac{1}{1-U h}\right)
$$

dengan $t=$ waktu yang diperlukan untuk mencapai $U h, D=$ diameter pengaruh 1 drain, $C h=$ koefisien konsolidasi tanah akibat aliran arah horizontal, $U h=$ derajat konsolidasi tanah akibat aliran air arah horizontal.

\section{Parameter Tanah untuk Penentuan Waktu Konsolidasi dengan PVD}

Diameter yang digunakan pada pola pemasangan PVD dapat dihitung dengan persamaan (Hansbo, 1979) (Mochtar, 2012):

Pola Segiempat :

$$
\mathrm{D}=1.13 \mathrm{~S}
$$

Pola Segitiga :

$$
\mathrm{D}=1.05 \mathrm{~S}
$$

dengan $\mathrm{D}=$ Diameter pengaruh 1 drain, $\mathrm{S}=$ Jarak antar PVD

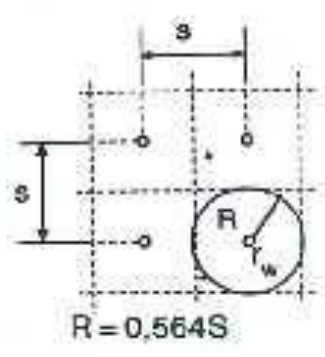

Pola bujur sanckar

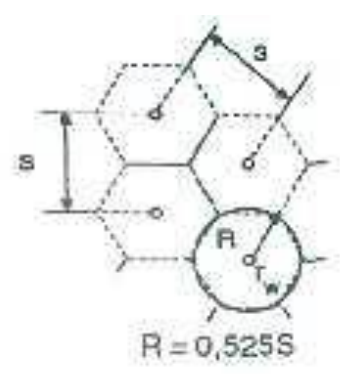

Polasegitiga

Gambar 3. Pola Pemasangan PVD (Soedarmo dan Purnomo, 2001)

Koefisien konsolidasi horizontal dapat ditentukan dari nilai koefisien konsolidasi vertikal $(C v)$ dengan persamaan (Hansbo, 1979) (Mochtar, 2012):

$$
C h=\left(\frac{k h}{k v}\right) C v
$$

dimana perbandingan antara koefisien permeabilitas horizontal (kh) dan vertical (kv) berkisar antara 2 sampai 5 kali koefisien konsolidasi vertikal. Dengan $\mathrm{Ch}=$ Koefisien konsolidasi horizontal, $\mathrm{Cv}=\mathrm{Koefisien}$ konsolidasi vertical, $\mathrm{Kh}=$ Koefisien permeabilitas horizontal, $\mathrm{Kv}=$ Koefisien permeabilitas vertical.

Perhitungan besar faktor hambatan yang diakibatkan jarak antar PVD dihitung dengan menggunakan persamaan di bawah ini. Pada umumnya $n>20$ sehingga dapat dianggap $1 / \mathrm{n}=0$ dan $\left(\frac{n^{2}}{n^{2}-1}\right)=1$, jadi (Hansbo, 1979) (Mochtar, 2012):

$$
F(n)=\ln (n)-\frac{3}{4} \text { atau } F(n)=\ln \left(\frac{D}{d w}\right)-\frac{3}{4}
$$


Metode Vacuum Consolidation dengan Preloading untuk

Jason Sastilaya, et al. Mempercepat Konsolidasi Tanah pada Perumahan di Tangerang.

$$
n=\frac{D}{d w}
$$

dimana dw adalah diameter dari vertical drain (equivalen terhadap bentuk lingkaran (Gambar 3) yang dapat diperoleh dengan persamaan :

$$
\mathrm{dw}=\frac{2(a+b)}{\pi}
$$

dengan $\mathrm{F}(\mathrm{n})=$ Faktor hambatan akibat jarak antar $\mathrm{PVD}, \mathrm{n}=$ rasio jarak, $\mathrm{D}=$ Diameter pengaruh 1 drain, a = Lebar PVD, $\mathrm{b}=$ Panjang PVD, $\mathrm{dw}=$ diameter equivalen dari vertical drain seperti pada gambar 4.

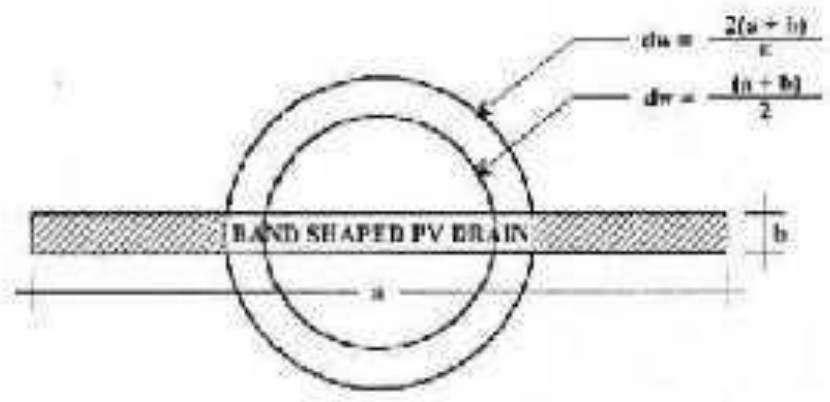

Gambar 4. Diameter equivalen (dw) untuk PVD (Mochtar, 2012)

Derajat konsolidasi rata-rata dapat diperoleh dengan persamaan (Mochtar, 2012):

$$
U=1-(1-U v)(1-U h)
$$

dengan $U=$ derajat konsolidasi tanah akibat aliran vertikal dan radial, $U v=$ derajat konsolidasi vertical, $U h=$ derajat konsolidasi radial.

\section{Parameter Tanah untuk Penentuan Derajat Konsolidasi dengan PVD}

Besar derajat konsolidasi arah vertical dapat ditentukan dengan persamaan berikut (Das, 2011):

$$
\begin{aligned}
& \text { Untuk } T v \text { antara } 0 \mathrm{~s} / \mathrm{d} 60 \%, U v=\left(2 \sqrt{\frac{T v}{\pi}}\right) \cdot 100 \% \\
& \text { Untuk } T v>60 \%, \quad U v=\left(100-10^{2}\right) \%
\end{aligned}
$$

Besarnya harga derajat konsolidasi horizontal dirumuskan oleh Barron (1948) dalam Bergado (1996) dengan persamaan:

$$
\begin{aligned}
& U h=1-\exp \left|\frac{-8 T h}{F(n)}\right| \\
& T h=\frac{C h . t}{D}
\end{aligned}
$$

dengan $T h=$ Faktor waktu arah horizontal, $C h=$ Koefisien konsolidasi horizontal, $D=$ Diameter pengaruh 1 drain.

\section{METODE PENELITIAN}

Daerah proyek perumahan Distrik 26 di Kosambi City memiliki luas 2,65 Ha dengan jenis tanah lempung yang sangat lunak sehingga memiliki waktu konsolidasi yang sangat lama. Permasalahan konsolidasi ini diperbaiki dengan menggunakan vacuum consolidation dengan preloading. Vacuum berfungsi menyediakan perbedaan tekanan sehingga mempercepat kecepatan aliran ke arah radial dan vertical drain dapat terjadi. Pemasangan prefabricated vertical drain (PVD) ialah memperpendek jarak aliran air drainase.

Pada penelitian ini pengumpulan data dilakukan dengan menggunakan data sondir Housing Distrik 26 Kosambi City. Dikarenakan data laboratorium tidak diperoleh, maka Indeks Pemampatan (Cc) menggunakan grafik korelasi qc dan Cc (Sanglerat, 1972) dan didapat Cc minimum sebesar 0,12 dan Cc maksimum sebesar 0,75. Setelah data parameter tanah yang dimiliki sudah cukup maka tahap selanjutnya adalah perhitungan penurunan konsolidasi. Perhitungan ini menggunakan beban timbunan setinggi 1,2 m, water surcharge setinggi 1,3 m, dan beban vacuum sebesar $80 \mathrm{kPa}$. Setelah perhitungan penurunan, maka dilanjutkan dengan pemasangan prefabricated vertical drain (PVD) dengan simulasi pemasangan pola segitiga dan pola segiempat dengan jarak antar PVD bervariasi untuk 
menentukan jarak antar PVD dengan waktu konsolidasi tercepat. Jarak antar PVD yang digunakan yaitu 0,8 m, 1 $\mathrm{m}, 1,25 \mathrm{~m}, 1,5 \mathrm{~m}, 1,75 \mathrm{~m}$, dan $2 \mathrm{~m}$. Hasil analisis disajikan dalam grafik.

\section{HASIL DAN PEMBAHASAN}

\section{Perhitungan Penurunan Konsolidasi}

Penurunan konsolidasi dihitung dengan beban timbunan 1,2 m, water surcharge 1,3 m, dan beban vacuum $80 \mathrm{kPa}$ berdasarkan persamaan (1) :

Tabel 1. Penurunan yang terjadi akibat pembebanan preloading (Cc minimum)

\begin{tabular}{ccccccc}
\hline \multicolumn{2}{c}{$\begin{array}{c}\text { Kedalaman } \\
(\mathrm{m})\end{array}$} & $\begin{array}{c}\text { Kedalaman Rata-Rata } \\
(\mathrm{m})\end{array}$ & $\mathrm{e}$ & $\mathrm{Cc}$ & $\mathrm{Cs}$ & $\begin{array}{c}\mathrm{\gamma}_{\text {sat }} \\
\left(\mathrm{kN} / \mathrm{m}^{3}\right)\end{array}$ \\
\hline 0 & 1,2 & 0,6 & 0,55 & 0,12 & 0,024 & 16 \\
1,2 & 7,2 & 4,2 & 0,875 & 0,25 & 0,05 & 15 \\
7,2 & 12 & 9,5 & 0,625 & 0,15 & 0,03 & 15 \\
\hline
\end{tabular}

Tabel 2. Penurunan yang terjadi akibat pembebanan preloading (Cc minimum)

\begin{tabular}{ccccccc}
\hline \multicolumn{2}{c}{$\begin{array}{c}\text { Kedalaman } \\
(\mathrm{m})\end{array}$} & $\begin{array}{c}\text { Po } \\
(\mathrm{kN} / \mathrm{m} 2)\end{array}$ & $\begin{array}{c}\Delta \mathrm{P} \\
\left(\mathrm{kN} / \mathrm{m}^{2}\right)\end{array}$ & $\begin{array}{c}\mathrm{Po}+\Delta \mathrm{P} \\
\left(\mathrm{kN} / \mathrm{m}^{2}\right)\end{array}$ & $\begin{array}{c}\text { Sc } \\
(\mathrm{m})\end{array}$ & $\begin{array}{c}\text { Sc kumulatif } \\
(\mathrm{m})\end{array}$ \\
\hline 0 & 1,2 & 3,6 & 100,2 & 103,8 & 0,13563 & \\
1,2 & 7,2 & 21 & 111 & 132 & 0,63868 & 0,7743 \\
7,2 & 12 & 48 & 111 & 159 & 0,23047 & 1,0048 \\
\hline
\end{tabular}

Tabel 3. Penurunan yang terjadi akibat pembebanan preloading (Cc maksimum)

\begin{tabular}{ccccccc}
\hline \multicolumn{2}{c}{ Kedalaman } & $\begin{array}{c}\text { Kedalaman Rata-Rata } \\
(\mathrm{m})\end{array}$ & $\mathrm{e}$ & $\mathrm{Cc}$ & $\mathrm{Cs}$ & $\begin{array}{c}\text { J }_{\text {sat }} \\
(\mathrm{mN})\end{array}$ \\
\hline 0 & 1,2 & 0,55 & & & & 16 \\
1,2 & 7,2 & 0,875 & 0,55 & 0,18 & 0,024 & 15 \\
7,2 & 12 & 0,625 & 0,875 & 0,5 & 0,05 & 15 \\
\hline
\end{tabular}

Tabel 4. Penurunan yang terjadi akibat pembebanan preloading (Cc maksimum)

\begin{tabular}{cccccc}
\hline \multicolumn{2}{c}{$\begin{array}{c}\text { Kedalaman } \\
(\mathrm{m})\end{array}$} & $\begin{array}{c}\Delta \mathrm{P} \\
\left(\mathrm{kN} / \mathrm{m}^{2}\right)\end{array}$ & $\begin{array}{c}\mathrm{Po}+\Delta \mathrm{P} \\
\left(\mathrm{kN} / \mathrm{m}^{2}\right)\end{array}$ & $\begin{array}{c}\text { Sc } \\
(\mathrm{m})\end{array}$ & $\begin{array}{c}\text { Sc kumulatif } \\
(\mathrm{m})\end{array}$ \\
\hline 0 & 1,2 & 100,2 & 103,8 & 0,18549 & \\
1,2 & 7,2 & 111 & 132 & 0,95803 & 1,1435 \\
7,2 & 12 & 111 & 159 & 0,59922 & 1,7427 \\
\hline
\end{tabular}

Contoh perhitungan penurunan:

Kedalaman 0 - 1,2 m:

- Beban timbunan:

Untuk beban timbunan dilakukan perhitungan sebagai berikut:

$\mathrm{H}_{\text {timbunan }}=1,2 \mathrm{~m}$ 
Metode Vacuum Consolidation dengan Preloading untuk

Mempercepat Konsolidasi Tanah pada Perumahan di

Tangerang.

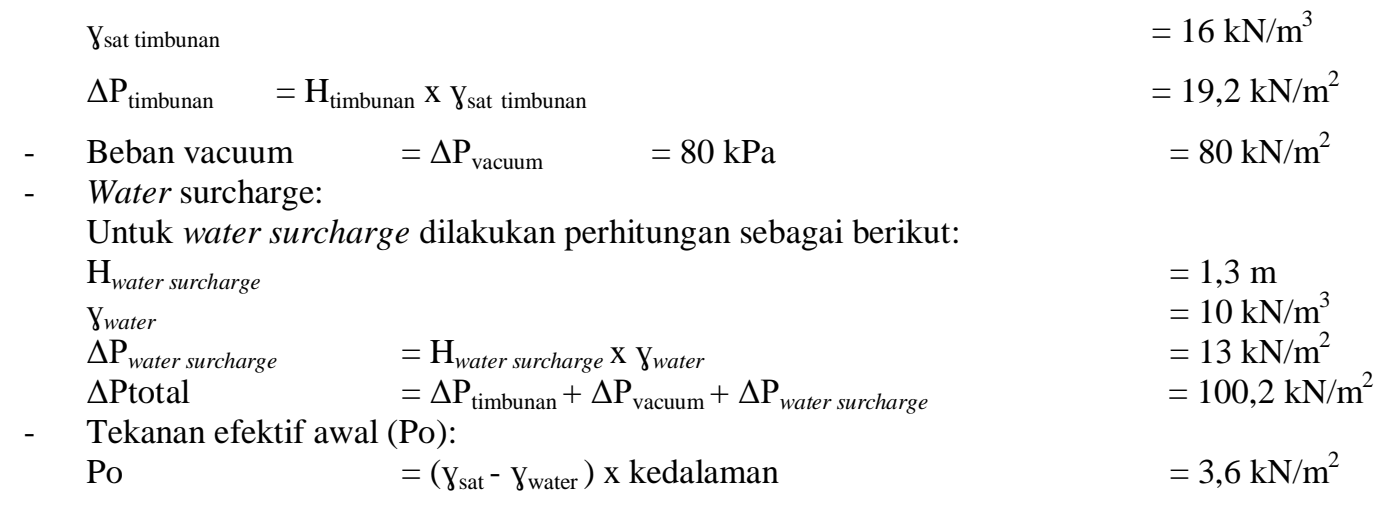

Kedalaman 1,2 - 7,2 m:

- Beban timbunan:

Untuk beban timbunan dilakukan perhitungan sebagai berikut:

$\mathrm{H}_{\text {timbunan }}$

$=1,2 \mathrm{~m}$

$\gamma_{\text {sat timbunan }}$

$\Delta \mathrm{P}_{\text {timbunan }}=\mathrm{H}_{\text {timbunan }} \mathrm{X} \mathrm{\gamma}_{\text {sat timbunan }}$

$=15 \mathrm{kN} / \mathrm{m}^{3}$

$=18 \mathrm{kN} / \mathrm{m}^{2}$

- Beban vacuum

$=\Delta \mathrm{P}_{\text {vacuum }}$

$=80 \mathrm{kPa}$

$=80 \mathrm{kN} / \mathrm{m}^{2}$

- Water surcharge:

Untuk water surcharge dilakukan perhitungan sebagai berikut:

$\mathrm{H}_{\text {water surcharge }}$

Ywater

$=1,3 \mathrm{~m}$

$\Delta \mathrm{P}_{\text {water surcharge }}$

$=\mathrm{H}_{\text {water surcharge }} \mathrm{X} \mathrm{\gamma}_{\text {water }}$

$\Delta$ Ptotal

$=\Delta \mathrm{P}_{\text {timbunan }}+\Delta \mathrm{P}_{\text {vacuum }}+\Delta \mathrm{P}_{\text {water surcharge }}$

$=10 \mathrm{kN} / \mathrm{m}^{3}$

$=13 \mathrm{kN} / \mathrm{m}^{2}$

- Tekanan efektif awal (Po):

Po

$=\left(\gamma_{\text {sat }}-\gamma_{\text {water }}\right) \mathrm{x}$ kedalaman

$=21 \mathrm{kN} / \mathrm{m}^{2}$

Kedalaman 7,2 - 12 m:

- Beban timbunan:

Untuk beban timbunan dilakukan perhitungan sebagai berikut:

$\mathrm{H}_{\text {timbunan }}$

$=1,2 \mathrm{~m}$

$\gamma_{\text {sat timbunan }}$

$\Delta \mathrm{P}_{\text {timbunan }}=\mathrm{H}_{\text {timbunan }} \mathrm{X} \mathrm{\gamma}_{\text {sat timbunan }}$

$=15 \mathrm{kN} / \mathrm{m}^{3}$

Beban vacuum

$=\Delta \mathrm{P}_{\text {vacuum }}$

$=80 \mathrm{kPa}$

$=18 \mathrm{kN} / \mathrm{m}^{2}$

- Water surcharge:

$=80 \mathrm{kN} / \mathrm{m}^{2}$

Untuk water surcharge dilakukan perhitungan sebagai berikut:

$\mathrm{H}_{\text {water surcharge }}$

$=1,3 \mathrm{~m}$

Ywater

$=10 \mathrm{kN} / \mathrm{m}^{3}$

$\Delta \mathrm{P}_{\text {water surcharge }}$

$=\mathrm{H}_{\text {water surcharge }} \mathrm{X} \mathrm{\gamma}_{\text {water }}$

$\Delta$ Ptotal

$=\Delta \mathrm{P}_{\text {timbunan }}+\Delta \mathrm{P}_{\text {vacuum }}+\Delta \mathrm{P}_{\text {water surcharge }}$

$=13 \mathrm{kN} / \mathrm{m}^{2}$

- Tekanan efektif awal (Po) :

$=111 \mathrm{kN} / \mathrm{m}^{2}$

Po

$=\left(\gamma_{\text {sat }}-\gamma_{\text {water }}\right) \times$ kedalaman

$=48 \mathrm{kN} / \mathrm{m}^{2}$

Berdasarkan perhitungan Tabel 1 sampai dengan Tabel 4, didapat penurunan konsolidasi dengan menggunakan Cc minimum sebesar 1,0048 $\mathrm{m}$ dan penurunan konsolidasi dengan menggunakan Cc maksimum sebesar 1,7427 $\mathrm{m}$. 


\section{Waktu Konsolidasi}

Derajat konsolidasi yang ingin dicapai adalah U 90\%, maka Tv didapat berdasarkan persamaan (11) sebagai berikut (Das, 2011):

$$
\begin{aligned}
\mathrm{Tv} & =1,781-0,933 \log (100-\mathrm{U} \%) \\
& =1,781-0,933 \log (100-90) \\
& =0,848
\end{aligned}
$$

Tv didapat 0,848 dan tebal lapisan drainase (Hdr) sebesar $12 \mathrm{~m}$ sehingga didapat waktu konsolidasi dengan persamaan (5) sebagai berikut (Das, 2011):

$$
\begin{aligned}
\mathrm{t} & =\frac{\mathrm{Tv} \cdot \mathrm{Hdr}^{2}}{\mathrm{Cv}} \\
& =\frac{0,848 \cdot 12^{2}}{0,027523} \\
& =4436,7256 \text { minggu } \\
& =85,0315 \text { tahun. }
\end{aligned}
$$

Karena waktu konsolidasi yang didapat sangat lama yaitu 85 tahun, maka digunakan Prefabricated Vertical Drain (PVD) untuk mempercepat waktu konsolidasi.

\section{Perencanaan Prefabricated Vertical Drain (PVD)}

Pada perencanaan ini, PVD dipasang sedalam $12 \mathrm{~m}$. Terdapat 2 pola pemasangan PVD yang akan digunakan yaitu pola segitiga dan pola segiempat dengan variasi jarak sebesar $0,8 \mathrm{~m}, 1 \mathrm{~m}, 1,25 \mathrm{~m}, 1,5 \mathrm{~m}, 1,75 \mathrm{~m}$, dan $2 \mathrm{~m}$. Jenis PVD berpengaruh untuk menentukan nilai dw, supaya didapatkan berapa derajat konsolidasi horizontal (Uh). Berikut spesifikasi dari PVD yang digunakan yaitu Lebar PVD (a) = $100 \mathrm{~mm}$ dan Tebal PVD (b) $=4 \mathrm{~mm}$. 1. Faktor Hambatan Akibat Pemasangan PVD (F(n))

Perhitungan ini berdasarkan persamaan (7), (8), (9), (10), (11), (12) sampai dengan persamaan (13). Hasil perhitungan fkctor hambatan PVD dapat dilihat pada Tabel 5 dan Tabel 6 di bawah ini.

Tabel 5. Perhitungan Faktor Hambatan PVD pada Pola Pemasangan Segitiga

\begin{tabular}{cccccccc}
\hline $\begin{array}{c}\text { Jarak PVD } \\
(\mathrm{S})\end{array}$ & $\mathrm{D}$ & $\mathrm{a}$ & $\mathrm{b}$ & $\mathrm{dw}$ & $\mathrm{n}$ & $\mathrm{F}(\mathrm{n})$ & $\mathrm{D}$ \\
$(\mathrm{m})$ & $(\mathrm{mm})$ & $(\mathrm{mm})$ & $(\mathrm{mm})$ & $(\mathrm{mm})$ & & & \\
\hline 0,8 & 840 & 100 & 4 & 66,2420 & 12,6807 & 1,79008 & 0,84 \\
1 & 1050 & 100 & 4 & 66,2420 & 15,8509 & 2,01323 & 1,05 \\
1,25 & 1312,5 & 100 & 4 & 66,2420 & 19,8137 & 2,23637 & 1,3125 \\
1,5 & 1575 & 100 & 4 & 66,2420 & 23,7764 & 2,41869 & 1,575 \\
1,75 & 1837,5 & 100 & 4 & 66,2420 & 27,7391 & 2,57284 & 1,8375 \\
2 & 2100 & 100 & 4 & 66,2420 & 31,7019 & 2,70637 & 2,1 \\
\hline
\end{tabular}


Metode Vacuum Consolidation dengan Preloading untuk

Mempercepat Konsolidasi Tanah pada Perumahan di

Tangerang.

Tabel 6. Perhitungan Faktor Hambatan PVD pada Pola Pemasangan Segiempat

\begin{tabular}{cccccccc}
\hline $\begin{array}{c}\text { Jarak PVD } \\
(\mathrm{S})\end{array}$ & $\mathrm{D}$ & $\mathrm{a}$ & $\mathrm{b}$ & $\mathrm{dw}$ & $\mathrm{n}$ & $\mathrm{F}(\mathrm{n})$ & $\mathrm{D}$ \\
$(\mathrm{m})$ & $(\mathrm{mm})$ & $(\mathrm{mm})$ & $(\mathrm{mm})$ & $(\mathrm{mm})$ & & & \\
\hline 0,8 & 904 & 100 & 4 & 66,242 & 13,6469 & 1,86351 & 0,904 \\
1 & 1130 & 100 & 4 & 66,242 & 17,0587 & 2,08666 & 1,13 \\
1,25 & 1412,5 & 100 & 4 & 66,242 & 21,3233 & 2,3098 & 1,4125 \\
1,5 & 1695 & 100 & 4 & 66,242 & 25,588 & 2,49212 & 1,695 \\
1,75 & 1977,5 & 100 & 4 & 66,242 & 29,8526 & 2,64627 & 1,9775 \\
2 & 2260 & 100 & 4 & 66,242 & 34,1173 & 2,7798 & 2,26 \\
\hline
\end{tabular}

2. Pemasangan PVD dengan Variasi Jarak pada Pola Segitiga

Berdasarkan hasil perhitungan derajat konsolidasi dan waktu konsolidasi dengan pemasangan PVD pola segitiga dengan jarak antar PVD 0,8 m, $1 \mathrm{~m}, 1,25 \mathrm{~m}, 1,5 \mathrm{~m}, 1,75 \mathrm{~m}$, dan $2 \mathrm{~m}$ maka didapat grafik pada Gambar 5 sebagai berikut:

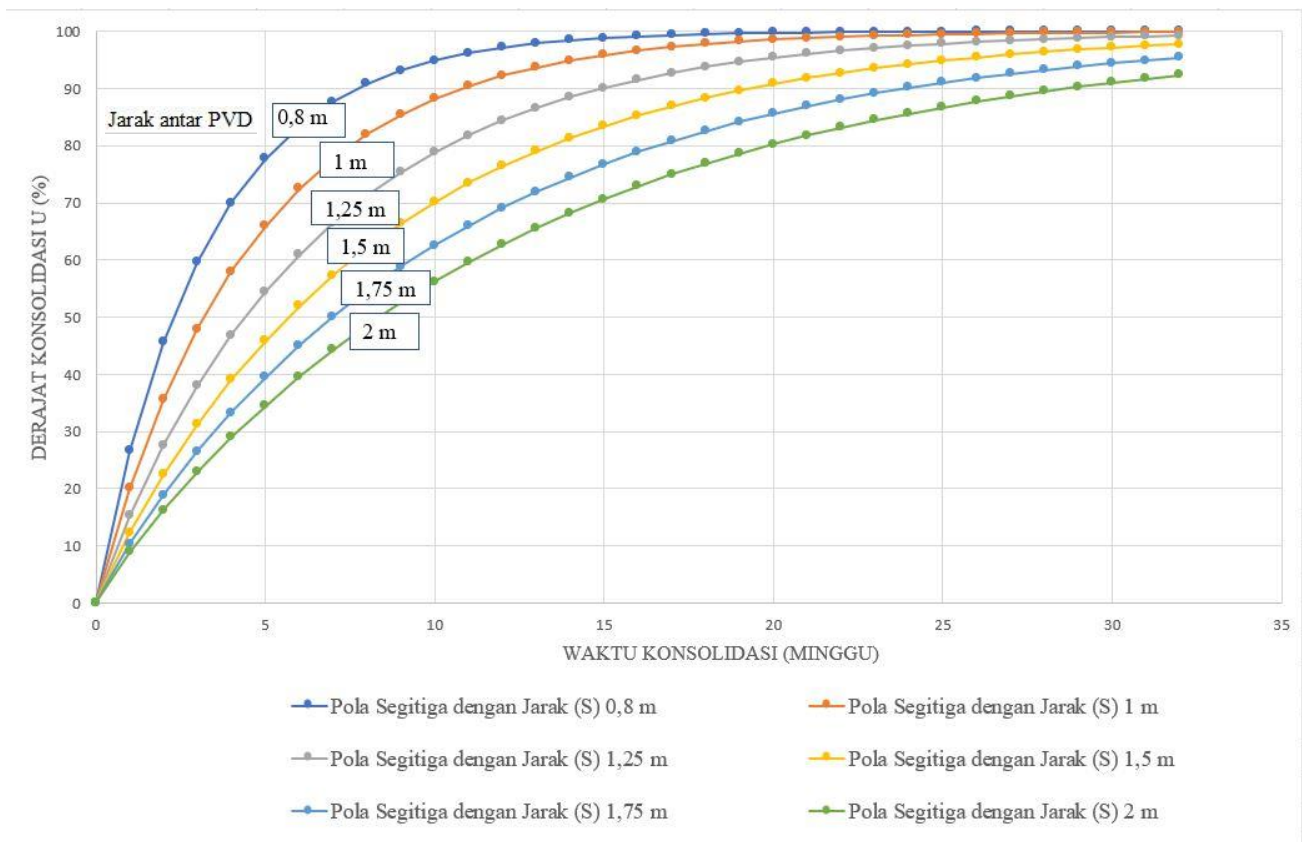

Gambar 5. Grafik Hubungan Derajat Konsolidasi dan Waktu Konsolidasi dengan Pemasangan PVD Pola Segitiga

Berdasarkan grafik pada Gambar 5, didapat waktu konsolidasi tercepat yang diperlukan untuk mencapai U 90\% terhadap jarak antar PVD dapat dilihat pada Tabel 7 sebagai berikut: 
Tabel 7. Perbandingan Waktu Konsolidasi untuk mencapai U 90\% dengan Jarak antar PVD Pola Segitiga

\begin{tabular}{|c|c|}
\hline \multicolumn{2}{|c|}{ Pemasangan PVD Pola Segitiga } \\
\hline Jarak Antar PVD & Waktu Konsolidasi untuk mencapai U 90\% \\
\hline$(\mathrm{m})$ & (minggu) \\
\hline 0,8 & 8 \\
\hline 1 & 11 \\
\hline 1,25 & 15 \\
\hline 1,5 & 20 \\
\hline 1,75 & 24 \\
\hline 2 & 29 \\
\hline
\end{tabular}

\section{Pemasangan PVD dengan Variasi Jarak pada Pola Segiempat}

Berdasarkan hasil perhitungan derajat konsolidasi dan waktu konsolidasi dengan pemasangan PVD pola segitempat dengan jarak antar PVD $0,8 \mathrm{~m}, 1 \mathrm{~m}, 1,25 \mathrm{~m}, 1,5 \mathrm{~m}, 1,75 \mathrm{~m}$, dan $2 \mathrm{~m}$ maka didapat grafik pada Gambar 6 sebagai berikut:

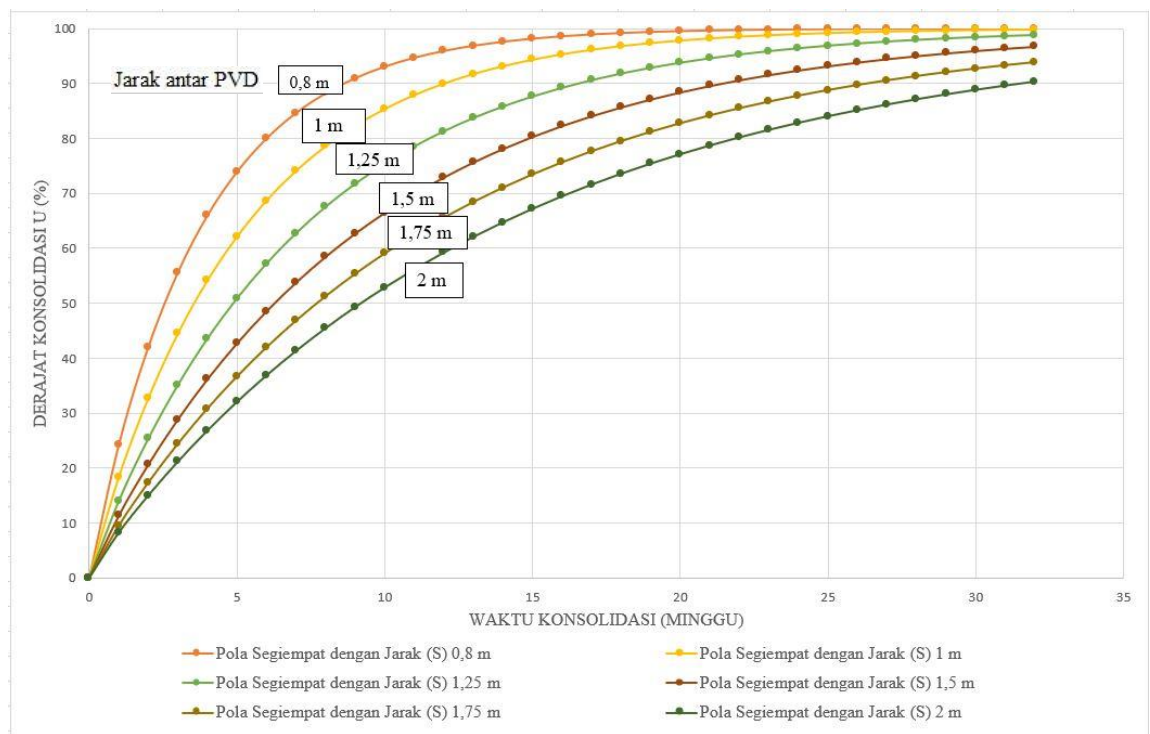

Gambar 6. Grafik Hubungan Derajat Konsolidasi dan Waktu Konsolidasi dengan Pemasangan PVD Pola Segiempat

Berdasarkan grafik pada Gambar 6, didapat waktu konsolidasi tercepat yang diperlukan untuk mencapai U 90\% terhadap jarak antar PVD pada Tabel 8 sebagai berikut: 
Metode Vacuum Consolidation dengan Preloading untuk Jason Sastilaya, et al. Mempercepat Konsolidasi Tanah pada Perumahan di Tangerang.

Tabel 8. Perbandingan Waktu Konsolidasi untuk mencapai U 90\% dengan Jarak antar PVD Pola Segiempat

\begin{tabular}{cc}
\hline & Pemasangan PVD Pola Segiempat \\
\hline Jarak Antar PVD & Waktu Konsolidasi untuk mencapai U 90\% \\
$(\mathrm{m})$ & 9 \\
\hline 0,8 & 13 \\
1 & 17 \\
1,25 & 22 \\
1,5 & 27 \\
1,75 & 32 \\
2 &
\end{tabular}

\section{Hubungan Penurunan Konsolidasi dengan Jarak Antar PVD}

Berdasarkan hasil analisis hubungan penurunan konsolidasi menggunakan Cc min dan Cc maks dengan pemasangan PVD pola segitiga dan pola segiempat dengan jarak bervariasi, maka didapat grafik-grafik pada Gambar 7, Gambar 8, Gambar 9, dan Gambar 10 sebagai berikut:

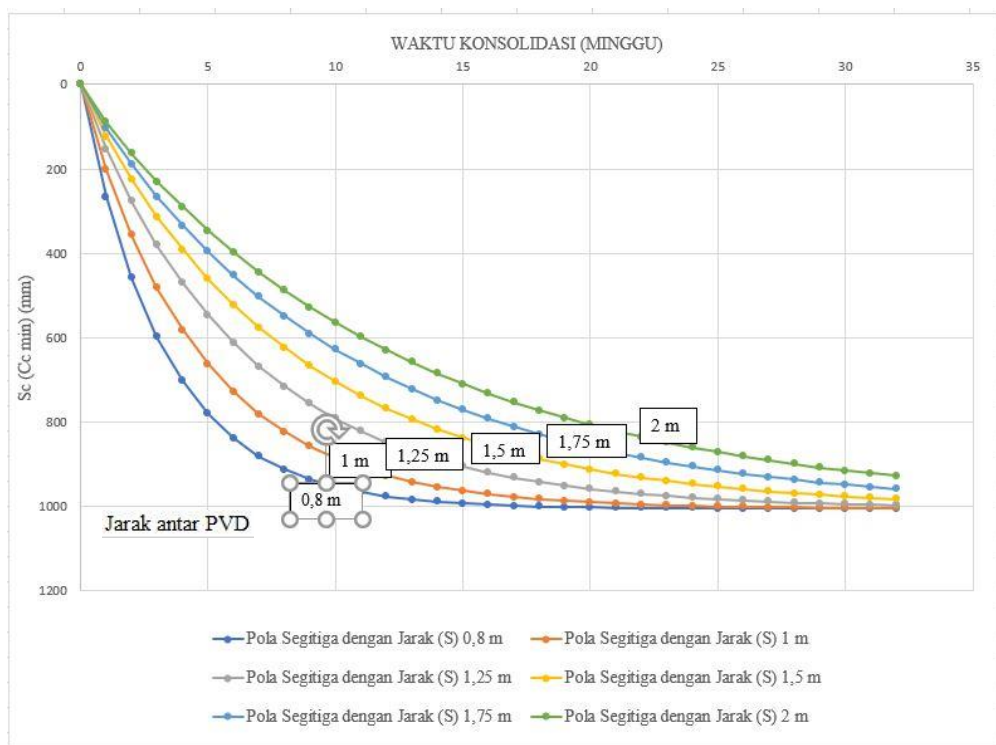

Gambar 7. Grafik hubungan penurunan konsolidasi (Ccmin) dengan jarak antar PVD pada pola pemasangan segitiga 


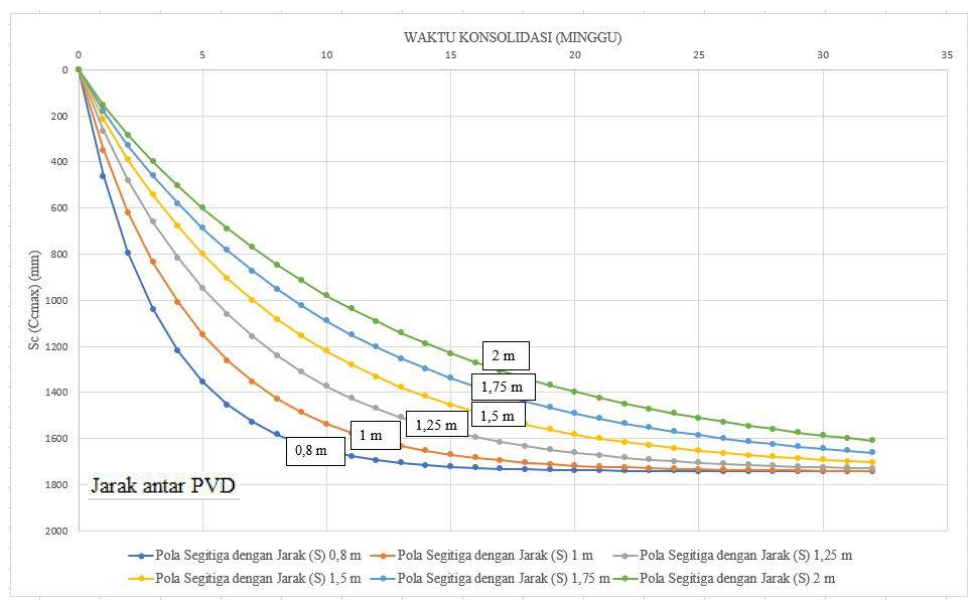

Gambar 8. Grafik hubungan penurunan konsolidasi (Ccmax) dengan jarak antar PVD pada pola pemasangan segitiga

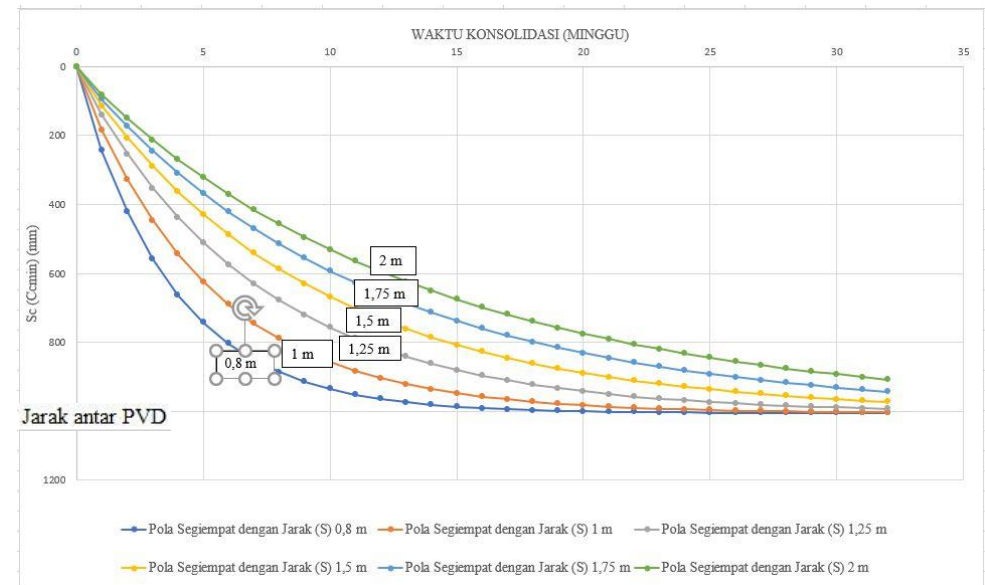

Gambar 9. Grafik hubungan penurunan konsolidasi (Ccmin) dengan jarak antar PVD pada pola pemasangan segiempat

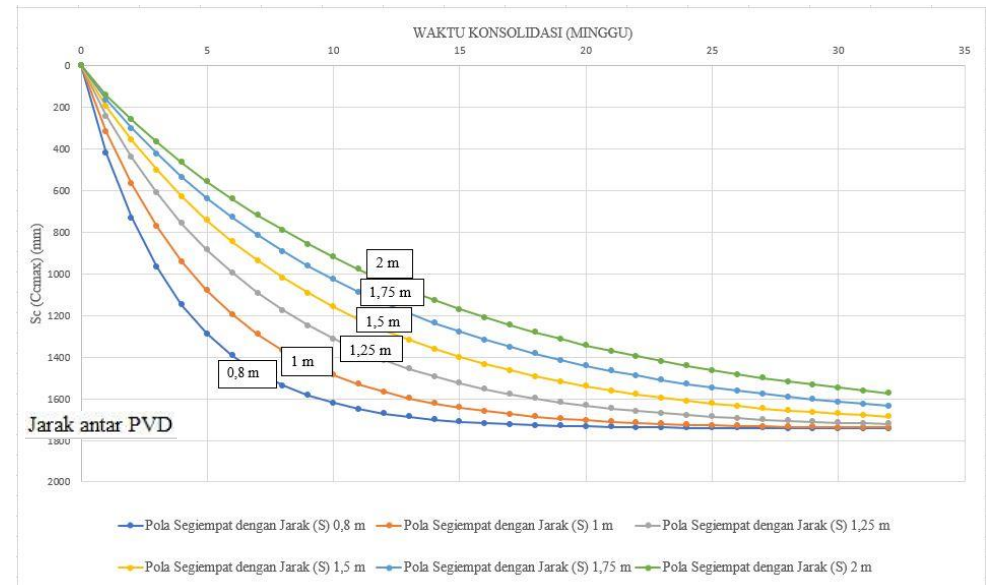

Gambar 10. Grafik hubungan penurunan konsolidasi (Ccmax) dengan jarak antar PVD pada pola pemasangan segiempat

Berdasarkan Gambar 7 sampai dengan Gambar 10, untuk mencapai penurunan konsolidasi sebesar 1004,8 mm (Ccmin) dan sebesar 1742,7 mm (Ccmax) dapat dicapai dengan rentang waktu 5 sampai 30 minggu dengan 
Tangerang.

mengatur jarak antar PVD pemasangan pola segitiga atau segiempat sebesar 0,8 m, $1 \mathrm{~m}, 1,25 \mathrm{~m}, 1,5 \mathrm{~m}, 1,75 \mathrm{~m}$, dan $2 \mathrm{~m}$ ditambah dengan pemanfaatan pompa vacuum.

Maka, berdasarkan Gambar 7 sampai dengan Gambar 10, bisa didapat waktu penurunan konsolidasi yang ingin dikehendaki. Semisal ingin menurunkan tanah selama 1 bulan, bisa dilihat tanah sudah turun sebesar $200 \mathrm{~mm}$ pada pola segitiga dan sebesar $200 \mathrm{~mm}$ pada pola segiempat.

\section{KESIMPULAN DAN SARAN}

\section{Kesimpulan}

Berikut ini merupakan kesimpulan yang dapat diambil dari hasil analisis metode vacuum consolidation dengan prefabricated vertical drain terhadap penurunan konsolidasi tanah pada Housing Distrik 26 Kosambi City, Tangerang:

1. $\quad$ Berdasarkan perhitungan metode Vacuum Consolidation dengan Prefabricated Vertical Drain (PVD) pemasangan pola segitiga dengan jarak bervariasi, waktu tercepat untuk mencapai derajat konsolidasi $90 \%$ yaitu pemasangan pola segitiga dengan jarak antar PVD $0,8 \mathrm{~m}$ yaitu 8 minggu. Sedangkan waktu terlama untuk mencapai derajat konsolidasi 90\% yaitu pemasangan pola segitiga dengan jarak antar PVD 2 m yaitu 29 minggu.

2. Berdasarkan perhitungan metode Vacuum Consolidation dengan Prefabricated Vertical Drain (PVD) pemasangan pola segiempat dengan jarak bervariasi, waktu tercepat untuk mencapai derajat konsolidasi $90 \%$ yaitu pemasangan pola segiempat dengan jarak antar PVD $0,8 \mathrm{~m}$ yaitu 9 minggu. Sedangkan waktu terlama untuk mencapai derajat konsolidasi 90\% yaitu pemasangan pola segiempat dengan jarak antar PVD 2 m yaitu 32 minggu.

3. Berdasarkan perhitungan metode Vacuum Consolidation dengan Prefabricated Vertical Drain (PVD) dengan jarak bervariasi, pemasangan Prefabricated Vertical Drain dengan pola segitiga lebih cepat dan efisien dalam mencapai waktu konsolidasi yang diperlukan dibandingkan pemasangan Prefabricated Vertical Drain dengan pola segiempat. Hal ini disebabkan pemasangan pola segitiga memiliki diameter pengaruh 1 drain (D) yang lebih kecil dibandingkan pemasangan pola segiempat.

\section{Saran}

Berdasarkan analisis yang telah dilakukan, berikut beberapa saran yang perlu diperhatikan untuk analisis lebih lanjut:

1. Diharapkan adanya hasil laboratorium yang lebih lengkap data pengujiannya agar hasil perhitungan dari analisis dapat lebih terperinci.

2. Untuk penelitian selanjutnya, disarankan juga untuk menggunakan metode perbaikan tanah yang lain untuk mempercepat waktu penurunan konsolidasinya.

\section{DAFTAR PUSTAKA}

Bergado, D, T. Soft Ground Improvement in Lowland and Other Environments. New York: Asce Press. 1996.

Das, Braja M. Mekanika Tanah I Jilid I. Jakarta: Penerbit Erlangga. 2011.

Djunaidy, Marcelo Wisal. Aplikasi Vacuum Consolidation Method. Jakarta: Geotalk XI. 2020.

Hardiyatmo, Hary Christady. Mekanika Tanah 2. Jogjakarta: Gadjah Mada University Press. 2010.

Mochtar, Noor Endah. Modul Ajar Metode Perbaikan Tanah. Surabaya: ITS Press. 2012

Sanglerat, G. The Penetrometer and Soil Exploration. Amsterdam: Elsevier Publishing Company. 1972.

Searle, I.W. The interpretation of Begemann Friction Jacket Cone Results to Give Soil Types and Design Parameters. Design Parameters in Geotechnical Engineering. London: BCS London. 1979.

Soedarmo G, Djatmiko dan S, J, Edy Purnomo. Mekanika Tanah 2. Malang: Kanisius. 2001.

Terzaghi, Karl. Theoretical Soil Mechanics. New York: Wiley. 1943. 